\title{
Spatial Information System for Heritage of Islam Banten Culture
}

\author{
$1^{\text {st }}$ Eva Khudzaeva ${ }^{1}, 2^{\text {nd }}$ Zainul Arham $^{1}, 3^{\text {rd }}$ M. N. Hanif Syafii ${ }^{1}$ \\ \{eva.khudzaeva@uinjkt.ac.id ${ }^{1}$, zainul.arham@uinjkt.ac.id ${ }^{1}$, hanif.safii11@mhsuinjkt.ac.id ${ }^{1}$ \} \\ UIN Syarif Hidayatullah, Information System Department, Science and Technology Faculty, Jakarta, \\ Indonesia $^{1}$
}

\begin{abstract}
Banten has a very close history to the glory of Islam. Remains of the glory of Islam can still be seen from the many Islamic cultural heritage in Banten. The number of Islamic cultural heritage is due to the history of Banten, which has an Islamic kingdom, the Banten Sultanate. The traces of the glory of Islam in Banten can still be seen from the remnants of historical heritage such as in the area of the old city of attack. To preserve the cultural heritage the education and culture services form the Cultural Heritage Conservation Center to carry out protection, development and utilization and facilitation of preservation of reserves. culture in the area of work. However, in applying the preservation of cultural heritage, BPCB still has constraints such as registration of cultural heritage that is still manual and the unavailability of a spatial information system on the distribution of cultural heritage causes a lack of information on cultural heritage. Based on this, researchers designed the Banten Islamic Heritage Spatial Information System to support cultural preservation activities. Designing this system the author performs several stages including the stages of requirements planning, workshop design and implementation using Rapid Application Development (RAD) system development methods and using the Unified Modeling Language (UML) tools. This research produces Heritage of Islam Banten cultural reserve spatial information system with the output in the form of web-based Islamic Spatial Information System Islamic Application. The developed system can be used by companies to provide information about Islamic cultural heritage and can assist the (Balai Pelestarian Budaya Banten) BPCB in collecting cultural heritage by using the cultural heritage registration feature. In addition, this system can also be used by the community to obtain information about Islamic cultural heritage and also facilitate the registration process of cultural heritage.
\end{abstract}

Keywords: Spatial Information System; Haritage of Islam Banten Culture; Rapid Application Development (RAD); Unified Modelling Languange (UML);

\section{Introduction}

Indonesia is the biggest archipelago country in the world. The total area of Indonesia is around $1,904,569 \mathrm{~km} 2$. The number of islands in Indonesia reaches $13,466 \mathrm{~km}$. Not only that, Indonesia has many ethnic groups, languages and customs that make Indonesia a great nation. Based on this diversity, Indonesia has a very diverse culture in it. This diversity cannot be separated from the long history of the Indonesian people who have long been in contact with other nations because of the trade process. Because of its strategic location with the trade route causing acculturation of culture. Foreign traders come to the archipelago by bringing 
their customs and culture as a result affecting the indigenous culture of the archipelago. This has an impact on cultural diversity in Indonesia.

Indonesia has a long history from prehistoric times to the era of independence. That can be seen from the many historical relics that still exist today or which can be called cultural heritage. Cultural heritage has important values for history, science, education, religion and culture. Cultural heritage has a unique, rare, fragile, non-renewable nature, cannot be replaced by the same technology and materials, and is important because it is evidence of past human activities. According to Law No. 11 of 2010 Cultural heritage is categorized into 5, namely cultural heritage objects, cultural heritage buildings, cultural heritage structures, cultural heritage sites, and cultural heritage sites on land and sea [1].

To preserve the cultural heritage the Ministry of Education and Culture issued a Regulation of Minister of Education and Culture No. 52 of 2012 established the Center for Preservation of Cultural Heritage has the task of carrying out protection, development and utilization and facilitation of preservation of cultural heritage in its working area. Conservation must be based on a feasibility study that can be accounted for academically, technically and administratively. In its implementation, cultural preservation activities must refer to laws and regulations, be carried out or coordinated with conservation experts and with due regard to the ethics of preservation.

It is noted that there are around 1390 cultural reserves that have been designated as provincial level cultural heritage by the Ministry of Education and Culture. In Banten there are 28 provincial cultural heritage sites and 227 district / city level cultural heritage objects. According to the Banten Center for Cultural Heritage Conservation, there are around 245 recorded cultural reserves. All recorded data are cultural heritage from prehistoric times to independence.

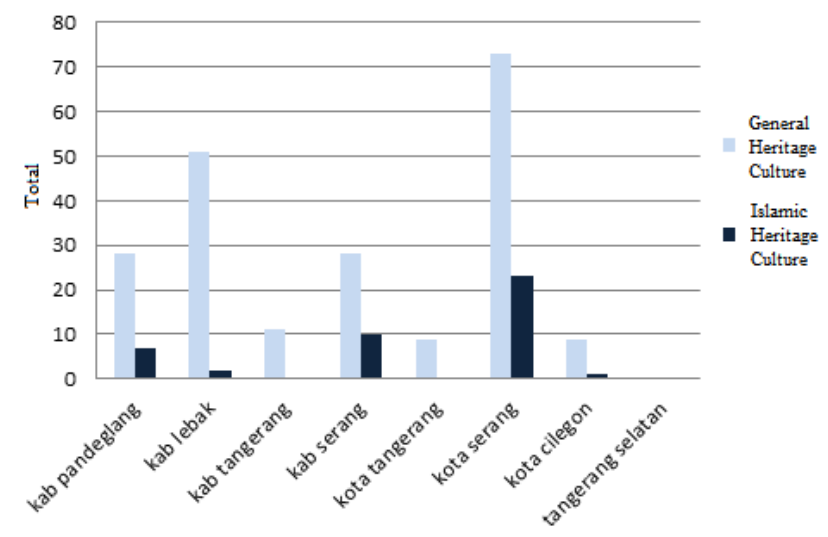

Figure 1. Chart of Number of General Cultural Heritage and Islamic Heritage in 2016

Banten Province is a province famous for its pilgrimage and religious tourism. That can be seen from the history of Banten which has an Islamic kingdom, namely the Sultanate of Banten. During the Banten Sultanate, the Banten Region experienced rapid development. Banten area is the center of trade on the island of Java and also as the largest Islamic study center in Southeast Asia. There are 44 Islamic cultural reserves that have been designated as cultural heritage, 25 are registered but not yet established, and 13 are not registered. 


\section{Total Islamic Culture Heritage}

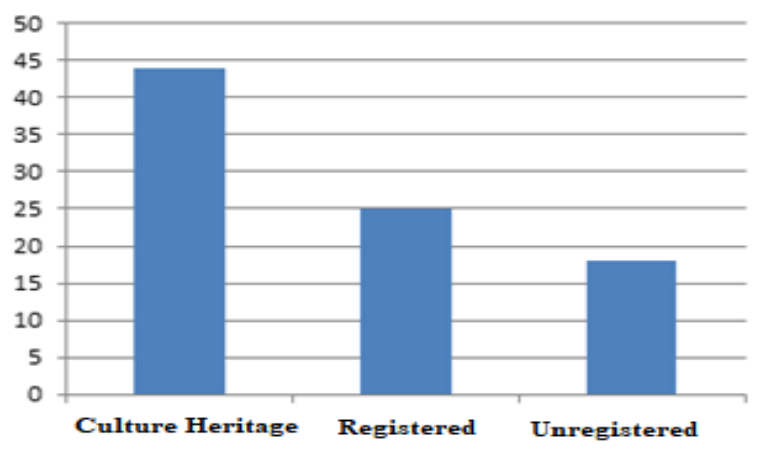

Figure 2. Graph number of Islamic cultural heritage in Banten Province in 2016

Current cultural heritage problems are caused by various things. The issue of ownership or control of cultural heritage, human activities such as development, in addition to the lack of attention from the government and the participation of the community in conservation so that cultural heritage is not maintained or damaged. On the other hand there are still many historical relics that have not been registered as cultural heritage by the government, causing them to be damaged or destroyed by human actions. Problems like this are often encountered but are difficult to prevent because the status of the cultural heritage has not been established. That is because there is still a lack of available data to make it a cultural heritage so that the cultural heritage is not maintained and damaged and may also be lost due to eroded development.

In Law No. 11 of 2010 paragraph 28 explained that the district/city government cooperates with everyone in registering. But in the implementation the Banten provincial government itself still uses registration manually. Whereas according to Law No. 11 of 2010 paragraph 30, namely the Government facilitates the establishment of a digital and / or nondigital system and network for registration of cultural heritage [1].

Referring to Law No. 11 of 2010 Article 95 paragraph 2 points "d" the Government and Regional Government in accordance with their level have the task of providing cultural heritage information for the community. However, the Banten Provincial Government itself has not provided cultural heritage information for the community. Whereas according to Law No. 11 of 2010 article 39 which reads the Government and Regional Government make an active effort to record and disseminate information about cultural heritage while still considering the security and confidentiality of data deemed necessary in accordance with the provisions of the legislation. But in its implementation the Banten provincial government was less active in providing information about cultural heritage [1].

With the technological advances that exist today we easily get information quickly and precisely. Geographic Information System (GIS) is a computer-based information system, designed to work using data that has spatial information (spatial references). This system captures, checks, integrates, manipulates, analyzes, and displays data that spatially references the location of the earth's surface. By using GIS we can utilize spatial data that is processed for the preservation of the cultural heritage. From the spatial data, the limits of the extent and space utilization can be determined through the zoning system. And from the zoning system, cultural heritage can be protected, developed and utilized easily. With the management of 3 
aspects of conservation it will provide results for the cultural heritage. This system is expected to help the government through institutions in registering, regulating and managing cultural heritage data, and can contribute knowledge to the historical development of Islamic culture, preserving it so that Indonesia always has a diversity of Islamic culture all the time that can be known, read and utilized by the whole community.

\section{Literature Review}

F. Petrescu 2007, The Use Of Gis Technology In Cultural Heritage', This paper is a report that attempts to describe the current status of GIS use in cultural heritage. Data provided by national CIPA delegates represent the main source of information on which the report is based [2].

MI. Santoso, Z. Arham and E. Khudzaeva, 2016, with title" Design of a web-based Geographic Information Systems Spatial for Distribution of Historic Site", Spatial information system can be designed based on archaeological site data which is located in the island of Java and the system was built using webBase system using Google Maps API that directly connected with Google Maps making it easier for the user to find the location of the site of history, besides that this system is also equipped with a direct location that can show the direction of the place of origin to the place where the site is located. [3]

G. Vacca, D.R. Fiorio and D. Pili 2017, This paper has the purpose of learning the techniques of building the 13-18th century in the region of Sardinia (Italy) for their knowledge, conservation and promotion. and was established with a multidisciplinary approach involving several specialists who integrated their expertise and provided their input for dimensional knowledge, technical constructs, menochemological, material, physicalmechanical, and energy performance features [4].

W. Lou, et al, 2017, his paper takes spatial analysis of Geographic Information Systems (GIS) as a basic technology and all history and cultural resources in Zhejiang Province of China as objects of research, and find accumulation and accumulation spaces Zhejiang Province's historic cities and cultural resources through overlay analysis and density analysis, etc. Then it will be discussed reasons for the formation of this accumulation area and accumulated belts by combining with physical geography analysis and historical geography and so on, and ultimately, linking tourism planning and traffic planning at the provincial level, providing advice on exhibitions and use of accumulated areas and accumulated belts from historical cities and cultural resources [5].

\section{Methods}

The author uses the system life cycle, Rapid Application Development (RAD).

\subsection{Phase Requirement Planning}

1. Data collection and information requirements

The researcher collected data and information through direct observation, interviews, and literature studies, so that the following data and information were obtained:

a. Profile of Banten Cultural Heritage Conservation Center. 
b. The organizational structure of the Banten Cultural Heritage Conservation Center.

c. Duties and functions of the Banten Cultural Heritage Conservation Center.

2. System Identification

After data and information is obtained, the author will identify the system to develop the existing system as follows:

a. Identifying Problems in a Running System Analyzing and identifying what are the weaknesses of the old system that is still running today

b. Proposed System Analysis Making recommendations in the form of a proposed system based on the identification of problems found in the running system as a solution to overcome the problems that exist in the old system.

\subsection{Workshop Design Phase}

1. Process design

a. Use Case Design

b. Activity Design

c. Sequence Design

d. Class Design

2. Database design

Researchers design and create a database of the Islamic spatial information system for Islamic cultural heritage. Database creation is done using the MySql server database.

3. Interface design

Researchers designed the interface, namely, the spatial information system of the Islamic cultural heritage of Banten. Customized views based on running system analysis related to cultural heritage so that users can not get into trouble when using the proposed system.

\subsection{Implementation Phase}

1. System development stages

In the initial stages, researchers made several maps needed in Banten Islamic cultural heritage spatial information system by digitizing and processing data and information collected using the ArcGis application. Then the researchers made the back end and front end systems in accordance with the analysis and design process that was made.

2. System testing stages

Researchers tested the proposed system using the blackbox testing method to ensure that there were no processes that were not in accordance with the design and design of the proposed system.

\section{Result}

\subsection{Requirement Planning}

Running System Analyst 


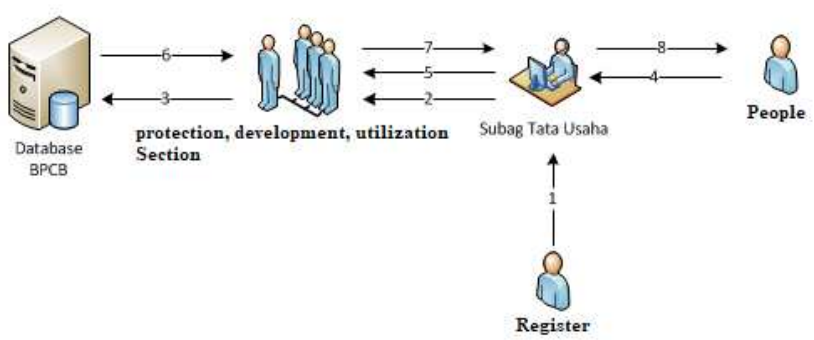

Figure 3. Running System Analyst

1. Members register cultural heritage to the BPCB by providing data to the subadministration

2. The protection, development and utilization section conducts verification of Cultural Heritage data

3. The protection, development and utilization section includes cultural heritage data in the database.

4. The community submits a letter of application to obtain cultural heritage data and information to the sub-administration

5. The administration sub-agency submits the application letter to the section on protection, development and utilization.

6. The protection, development and utilization section retrieves data from the database

7. The protection, development and utilization section provides data to the subadministration.

8. The administration sub-agency provides data in accordance with community requests.

\section{Proposed System}

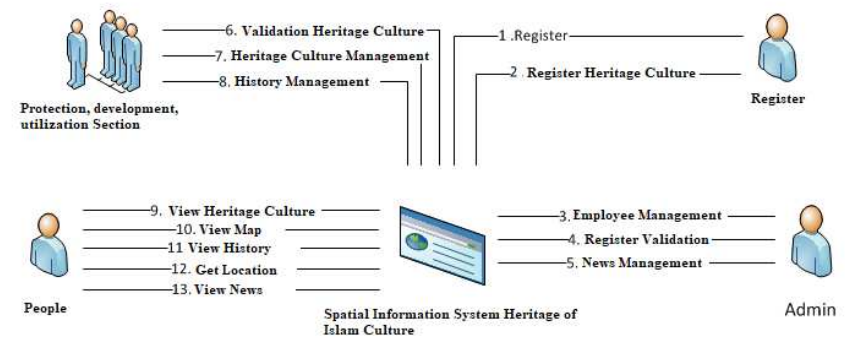

Figure 4. Proposed System

1. Member registers to create an account on the system.

2. Member registers cultural heritage owned.

3. Admin manages employee accounts in the system.

4. Admin validates registered member accounts. 
5. News Management Admin about cultural heritage.

6. The protection, development and utilization section validates the registered cultural heritage.

7. The protection, development and utilization section carries out the management of cultural heritage that has been recorded in the BPCB inventory.

8. Section for protection, development and utilization of historical management.

9. The public sees the registered cultural heritage data.

10. The community accesses the map to see the spread of Islamic cultural heritage.

11. People see the history of Islam in Banten.

12. People access to the location to see the fastest route to cultural heritage.

13. People access news to see the latest news related to Islamic cultural heritage.

\subsection{Workshop Design}

\section{Usecase Diagram}

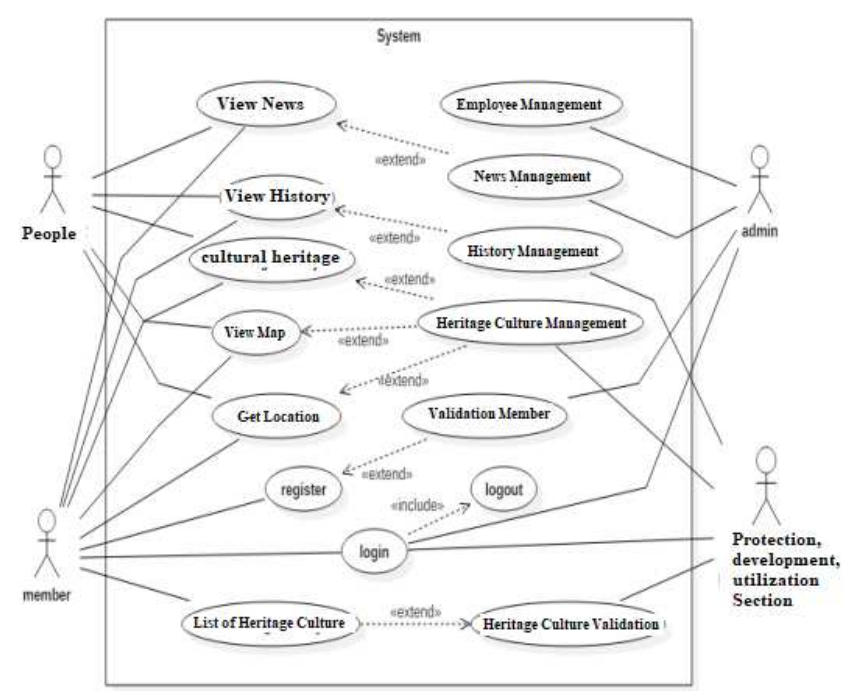

Figure 5. Usecase Diagram Of Spatial Information system Heritage of Islam Banten Culture.

\section{Class Diagram}




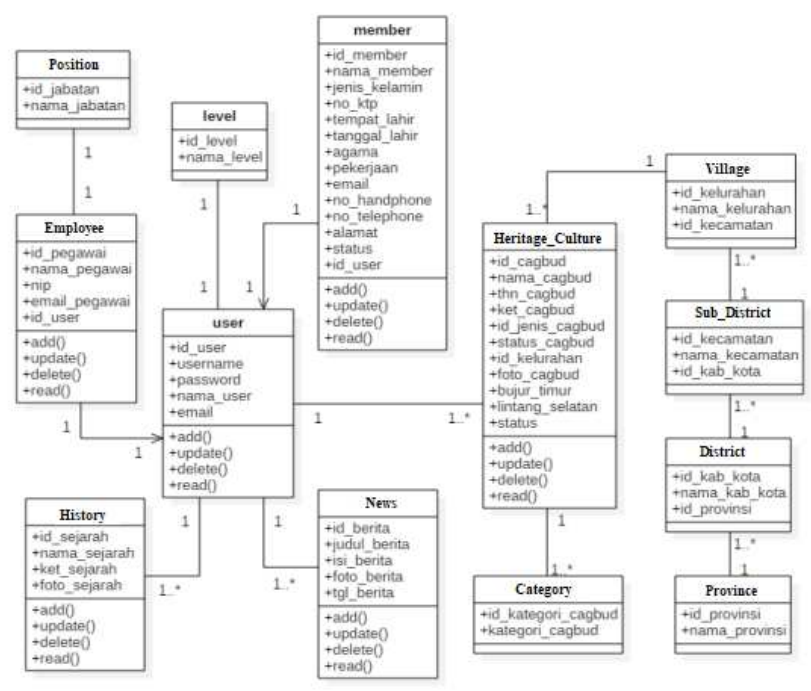

Figure 6. Class Diagram

\section{Design Interface}

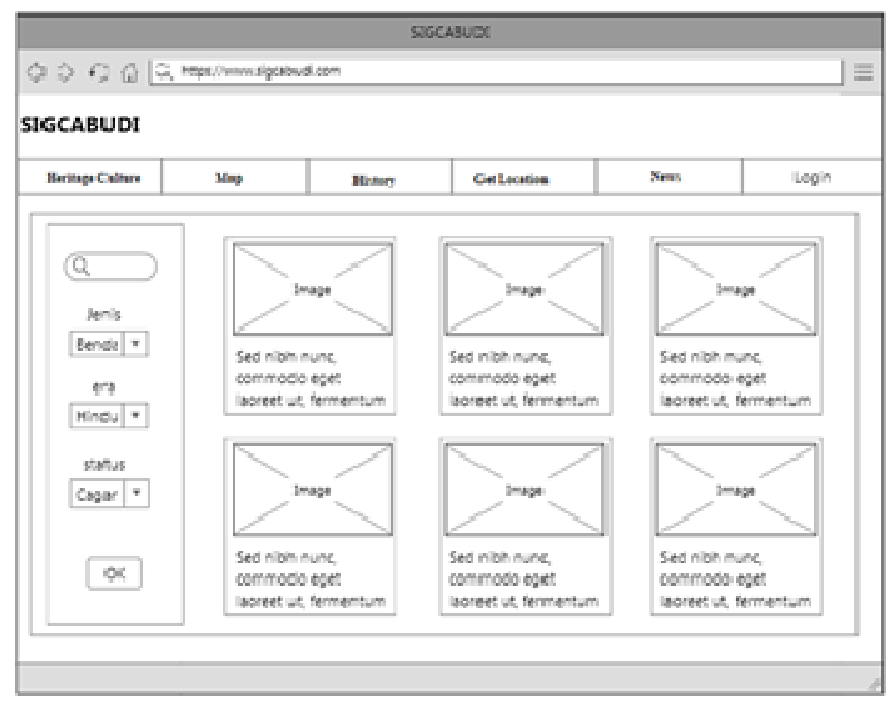

Figure 7. Usecase Diagram Of Spatial Information system Heritage of Islam Banten Culture.

\section{Conclusion}


1. The Islamic cultural heritage spatial information system is expected to help BPCB Banten to provide cultural heritage information to the community.

2. The spatial information system of Islamic cultural heritage provides a distribution map of Islamic culture that can be used to store information and history about Islamic culture in Banten.

3. The spatial information system of Islamic cultural heritage provides an online cultural heritage registration system to make it easier for people to register cultural heritage.

Acknowledgements. This paper in conjuction with The 1st International Conference on Islam, Science and Technology (ICONIST 2018) in Malang, East Java.

\section{References}

[1] Undang-Undang Republik Indonesia Nomor 11 Tahun 2010 Tentang Cagar Budaya.

[2] F. Petrescu (2007), "The Use Of Gis Technology In Cultural Heritage”, XXI International CIPA Symposium, 01-06 October 2007, Athens, Greece.

[3] MI. Santoso, Z.Arham and E.Khudzaeva (2016), "Design of a web-based Geographic Information Systems Spatial for Distribution of Historic Site" in 4th International Conference on Cyber and IT Service Management , Bandung , 2016.

[4] G. Vacca, D.R. Fiorio and D. Pili, (2017), "A Spatial Information System (SIS) for the Architectural and Cultural Heritage of Sardinia (Italy)", International journal Geo Information. ISPRS Int. J. Geo-Inf. 2018, 7, 49; doi:10.3390/ijgi7020049.

[5] W. Lou, et al, (2017). "Spatial Integration Analysis Of Provincial Historical And Cultural Heritage Resources Based On Geographic Information System (Gis)—A Case Study Of Spatial Integration Analysis Of Historical And Cultural Heritage Resources In Zhejiang Province". The International Archives of the Photogrammetry, Remote Sensing and Spatial Information Sciences, Volume XLII-2/W5, 2017 26th International CIPA Symposium 2017, 28 August-01 September 2017, Ottawa, Canada. 